\title{
MORAL ASPECTS IN THE MAIN CHARACTER OF STRANGE CASE OF DR JEKYLL AND MR. HYDE
}

\author{
Sugianti Somba \\ Program Studi Pendidikan Bahasa Inggris \\ Fakultas Bahasa dan Seni Universitas Indraprasta PGRI \\ somba_cute_08@yahoo.com
}

\begin{abstract}
Strange Case of Dr Jekyll and Mr. Hyde's novel that is full range of emotion, incident, mystery and horror aspects, which makes the reader's feeling unsteady. This novel tells us about a dual personality much depicted in plays and films, also influential in the growth of understanding of the subconscious mind through its treatment of a kind and intelligent physician who turns into a psychotic monster after imbibing a drug intended to separate good from evil in a personality. The purpose of this study is to describe the moral aspects in the main character in Strange of Dr. Jekyll and Mr Hyde. In this research method, the writer used two sources of data, the main source and the secondary source. The main source is taken from novel entitled Strange Case of Dr Jekyll and MR Hyde and the secondary source is taken from Internet, and furthermore. The result of this research showed that moral aspects of Mr. Utterson; as an individual is a good person; he had good relation to society and he had a good relation to God. So he is a kind person.
\end{abstract}

Keywords: moral aspects, main character

\begin{abstract}
ABSTRAK
Novel Strange Case of Dr Jekyll and Mr. Hyde's melibatkan aspek emosi, peristiwa, misteri dan horror yang mana membuat perasaan pembaca luluh. Novel ini menceritakan pada kita tentang kepribadian rangkap yang banyak lakon dan film, dan juga berpengaruh dalam perkembangan dari pemikiran bawah sadar melalui perawatan yang baik dari dokter yang professional yang meminumkan obat kepada orang gila agar bisa memisahkan pribadi yang baik dari jahat. Tujuan dari penelitian ini adalah untuk menggambarkan aspek aspek moral didalam karakter utama pada novel Strange of Dr Jekyl and Mr Hyde. Didalam metode penelitian ini, penulis menggunakan dua sumber data utama, pertama adalah diambil dari novel yang berjudul Starange Case of Dr Jekyll and Mr Hyde dan kedua diambil dari Internet. Hasil dari penelitian ini menunjukkan bahwa aspek - aspek moral dari Mr Utterson yakni sebagai orang yang baik; dia mempunyai hubungan yang baik dengan masyarakat dan dia memiliki hubungan yang baik dengan Tuhan. Sehingga dia adalah seorang manusia yang baik.
\end{abstract}

Kata Kunci: aspek moral, tokoh utama

\section{INTRODUCTION}

Literature has been known since twenty century. Before people recognized the written language, they have attended the literature into spoken literature. When the literature has included in the writing of the word, it can be enjoyed the word by the kinds of interesting story. Literature has its own way in entertaining the readers; it also educates and gives something valuable to the readers. Novel is part of literature and it is the long prose. There are so many kinds of novel; they are historical, apprenticeship, romance, comedy, tragedy, horror, etc. Novel is a kind of literature that people enjoyed. Factor factor is caused that it can be enjoyable by society because novel gave the human being appreciated lesson. Novel governs other literary forms, but there are not obligatory structure, style and subject matter. Novel has a story that gives a free of story, and it made something a lot, more detail, undergone the problems more complex.

In each the literature writing include novel, the writer describes the idea, value of life by the story of novel. Many people like reading novel because it giving the appreciated lesson to the human being.

Talking about the writing literature, the definite literature has the growth of the elements; one of them is the characters in the novel, and it is the role play important in the novel. Because it makes the story become an interesting or uninteresting in the novel, the next, based on the character in the novel, it can be known the good and worst character, and character is made the writer in the novel which it can be the variety story. So people 
are interested to read it and trying to get, and read the novel.

In this study the writer discussed about the novel Strange Case of Dr Jekyll and Mr Hyde is one Robert Louis Stevenson's Novel that tells us a horror story. One particular pleasures of reading Robert Louis Stevenson's Novel especially Strange Case of Dr. Jekyll and Mr Hyde that full range of emotion and horror aspects which make the readers feeling unsteady. This novel tells about a dual personality much depicted in plays and films, also influential in the growth of understanding of the subconscious mind through its treatment of a kind and intelligent physician turns into a psychopathic monster after bombing a drug intended to separate well from evil in a personality.

There are some researcher has been researched about the Moral value as follow;

1. Niek Niek Komala, August 14th 2001, she wrote, "Moral Values in Oliver Twist", a research paper submitted to the Faculty of Letters as a partial fulfillment of the requirement. She talked about moral values could be found in a person as an individual and as the member of society. She explained what she could find in Oliver Twist are: a) Religious Value means Religious person tends to have a good moral condition, but it depends on the individually; b) Individual Value means In this value there is no pressure from law, religion or society. It is pure from the conscience that comes from within the heart of someone. c) Social value means Social value is the most important aspect for moral. This value is about relation of human being with others. This is where people have to relate to other people in the society and how to keep the value that already existed since their ancestor.

2. Margaretha, July 10th 2003, She wrote,"Moral values in John Steinbeck's The Moon is Down', a research paper submitted to the Faculty of Letters as a partial fulfillment of the requirement for Diploma III in English, Gunadarma University.

\section{THEORETICAL FRAMEWORK}

According to Robert (2002:3) "Literature, like all art, is one of the essential thongs that make human beings human. In one way or another, everyone is touched by it." In other words, Literature made the man more courteous because it touched all aspect the entering soul. For an example when somebody read novel about the fight person to get the success, the readers felt in getting same success.

According Birkerts (2002:13) stated that human being in applying nice language by kinds of story or poetry. So when someone red kinds of story or poetry she / he get satisfy in the nice language.

Based on the definition above we get conclude that Literature can be differed into several parts such as poetry, fiction, essay, critic, and drama. But in this study, the writer is also limited into one kinds of literature is novel, and it is as a part of fiction story.

In general, novel consists of 40.000 words and more complicated than short story, it can not be limited of structural and metrical or prose. Novel talked about the character of the actor or actress in their life, it focused to the strange side of the narrative.

According to Feldman (2007: R15) stated that: "A novel is a long work of fiction. Novels contain such as characters, plot, conflict, and setting." Based on this statement novel has some elements such as character, plot, conflict, and background.

According to The New Oxford of English (Oxford University: 1998), "character is the mental and moral qualities that make up a person's nature.

According to Collins Concise Dictionary (Harper Collins: 1999)," is the combination of traits and qualities distinguishing the individual nature of a person of thing; a person represented in a film, or story. Based on the novel the author explains all things in detail when they used narrative and showing is in other hand; the author lets the character explain about themselves through dialogue and their actions, no one from this method can be said better or more interesting."

"Main character is the first person or people in drama or novel (Webster: 1995). Meanwhile supporting character is the supporting character or the supporting people 
or second to support the first people of drama or novel (Webster: 1995)

\section{RESEARCH METHODOLOGY}

In this study a qualitative research methods is used by the writer to explore the morality aspects of the main character in the novel Strange Case of Dr. Jekyll and $\mathrm{Mr}$ Hyde. Qualitative research is different from quantitative research; it does not quantitative research; it does not use statistical procedures as in quantitative research.

In Reasearch Design in Occupational Education, James from Oklahoma State University stated that:

"Qualitative research is a generic term for investigative methodologies described as ethnographic, naturalistic, anthropological field, or participant observer research. It emphasizes the importance of looking at variables in the natural setting in which they are formed (James, 2007:1)". In other words, the qualitative research stresses the useful of the variables in the pure situation in which they are formed.

Qualitative research affords to describe the phenomena into the text. Novel is one of the literatures that text formed. The core of qualitative research is descriptive and interpretative. The population of this research is the source of data that using by the writer as an object of research. The writer used the novel Strange Case of Dr. Jekyll and Mr. Hyde was published in 1991. The sample of the data is the moral aspects of the main character that the writer wanted to discuss in this study. There are some steps that the writer used to take this research were: 1) Reading the novel Strange Case of Dr. Jekyll and Mr Hyde; 2) Making the brief synopsis of the novel Strange Case of Dr. Jekyll and Mr. Hyde; 3) Identifying the moral aspects of Mr. Utterson in Strange Case of Dr Jekyll and Mr. Hyde; as an individual, his relation to society, and his relation to God.

\section{DISCUSSION}

Strange Case of Dr Jekyll and $\mathrm{Mr}$ Hyde novel tells about a dual personality much depicted in plays and films, also influential in the growth of understanding of the subconscious mind through its treatment of a kind and intelligent physician who turns into a psychopathic monster after imbibing a drug intended to separate well from evil in a personality.

1. Moral aspects of Mr. Utterson as an individual

a. "But he had and approved tolerance for others; sometimes wondering, almost with envy, at the high pressure of spirit involved in their misdeeds; and in any extremity inclined to help rather than to reprove."(Page 1)

Based on the paragraph above tells that $\mathrm{Mr}$ utterson had an approved tolerance for others and in any extremity inclined to help rather than to reprove this statement that reflects that Utterson is a kind person even though as and individual Utterson rarely out from his house, he was a man of a rugged countenance that never smile, cold scanty and yet somehow loveable. But Utterson still had a tolerance to others.

b. "It is the mark of a modest man to accept his friendly circle ready made from the hands of opportunity; and that was the lawyer's way. His friends were those of his own blood or those whom he had known the longest; his affections, like ivy, were the growth of time, they implied no aptness in the object." (Pages 1-2).

Based on the statement above the writer conclude that Utterson is a good moral as an individual because he can accepted the friends of different background and he realized that friend is really important for his life.

c. And the lawyer, scared by the though, brooded a while on his own past." (Pages 16)

"His past was fairly blameless; few men could read the rolls of their life with less apprehension; yet he was humbled to the dust by the many ill things he had done and raised up again into a sober and fearful gratitude by the many he had come so near to doing, yet avoid."(Pages 16)

Utterson realized that he had ever done a sin so he was afraid of God's punishment and he regretted for all done in the past and he never done it. He had a good moral as an individual. 
d. "Utterson sighed deeply but said never words; and the young man presently resumed. "Here is another lesson to say nothing, "said he."I am ashamed of my long tongue. Let us make a bargain never to refer to this again'. "With all my heart "said the lawyer."I shake hands on that. Richards.'(Pages 7)

Based on the statement above the writer conclude that he is a good moral because he felt so strange from his explanation and he believed to the man became the witness.

\section{Moral Aspects of Mr Utterson in his relation to society}

a. "I suppose, Lanyon, "said he, you and I must be the two oldest friends that Henry Jekyll has?" I wish the friends were younger," chuckled Dr Lanyon. "But I suppose we are. And what of that?"I see little of him now."'Indeed?"said Utterson." I though you had a bond of common interest." "We had, "was the reply."But it is more than ten years since Henry Jekyll became too fanciful for me; he began to go wrong, wrong in mind. (Pages 10).

When he met Lanyon, Utterson asked Lanyon to care and help to their old friends because Utterson didn't want something happened to his friend. Utterson tried to tell the problem because he though that Lanyon did not know yet to the problem of Dr Jekyll, but in fact Lanyon. Based on the statement above Utterson had a good moral in his relation to society.

b. "Poor Harry Jekyll. "He though" (Pages 16). "What Jekyll' he cried, "I trust you are better."'I am very low, Utterson,"replied the doctor drearly,'very low. It will not last long, thank God," 'You stay too much indoors,' said the lawyer, "you should be out, whipping up the circulation like $\mathrm{Mr}$ Enfield and me'."Come now; get your hat and take a quick turn with us'."You are very good, "signed the other. "I should like to very much; but no, no, no, it is quiet impossible; I dare not. But indeed, Utterson, I am very glad to see you; this really a great pleasure."(Pages 37)

"What!" he though."Henry Jekyll forgets for a murderer!' A blood ran cold in his veins."(Pages 30)

The writer conclude that he has a good moral because He didn't believe that his old friend forged the murder and he believed to the friends before he seen his own eyes.

c. "I wish you to promise me that you will bear with him and get his right for him, Utterson heaved an irrepressible sigh."Well." said he, "I promise."(Pages 19).

He didn't want to approve it but he felt his friend need his help, but at least Utterson approved to promise. Based on the statement that the writer is a good person.

3. Moral aspects of Mr. Utterson in his relation to God

a. "Even his friendship seemed to be found in a similar catholicity of good nature."(Page 1)

The writer concludes he had a good moral in his relation to God because Mr. utterson often goes to the church or any place where has catholicity good nature to prying or doing something that is religious.

b. "Until the clock in the neighboring church rang out the hour of twelve, when he would go soberly and gratefully to the bed. (Pages 8).

The statements above it is said Utterson says' gratefully' when he wants to go to bed, it is mean that he liked to thank to God, so the writer could conclude that Utterson had a good moral in his relation to God.

\section{c. Good God! Thought Mr.} Utterson."(Pages 13)

Based on the statement above that $\mathrm{Mr}$ Utterson liked to thank to God with saying 'good God", so the writer could conclude that Utterson had a good moral in his relation to God.

d. "God bless me, the man seems hardly human!(Pages 14)

Mr. Utterson liked to ask help to God with saying" God bless me," So the writer could conclude that Utterson had a good moral in his relation to God.

e. "God forgive us, God forgive us."Said Mr. Utterson (Pages 37)

He asked forgiveness for his fault to the God based on the statement above, so the writer conclude he was a good person. 


\section{CONCLUSION}

\section{Moral aspects of Mr. Utterson as an individual}

Individual moral focused to individuals in relation to him and people make the right or wrong within his own conscience. Mr. Utterson as the main character in this novel, from start to finish as an individual Mr. Utterson is a kind person, he had tolerance to other peoples, he concerns to his friends healthy,

\section{Social moral}

In his social interaction, Mr. Utterson cared of their old friends. Utterson concerned to the problem of the people, to what will happen to the child in every square in the town when they met Hyde, nice to the people around him. Social moral concern a human being in his relation to other human being or his society

\section{Religious Moral}

Religious moral refers to human being in his relation to a natural being or beings. Mr. Utterson Religion is Catholic, it was mentioned in Strange Case of Dr Jekyll and Mr. Hyde's novel and has relation to God, Mr Utterson had good moral. He appreciated and believed that there was God. Mr. Utterson met his friend in the church because he often comes to the church, he liked to thank to God with saying good God, he asked forgiveness for his fault to God, and he believed that the law of God existed, so that he had good relation to God

\section{SUGGESTION}

Strange Case of Dr Jekyll and Mr. Hyde's novel contain much moral application in it, because the novel has a lot of characters, event and mystery. Each of character has different attitude, behavior, background, point of view, respect or perhaps different philosophy. So, the writer suggest to the reader if the reader wants to discuss about the moral values in the novel, it is better to choose Strange Case of Dr. Jekyll and Mr. Hyde.

\section{BIBLIOGRAPHY}

Feldman, Kevin. 2007. Literature. Boston, Printice Hall

Perarsall, Judy. 1998-2001The New Oxford Dictionary of English New York: Oxford University Press, Inc.

Robert, Edgar. 2002. Literature: An Introduction to Reading and Writing, New Jersey: Englewood Cliffs.

Siswantoro, 2006. Penelitian Karya Sastra: Analisis Psikologis. Surakarta Muhammadiyah University Press.

Sinclair, Jim Collins Concise Dictionary. Glasglow: Harper Collins Publisher, 1999

Webster's, 2002. Merriam Webster's Collegiate Dictionary Tenth Edition, Massachusetts, Inc. 